Check for updates

Cite this: Med. Chem. Commun., 2018, 9, 10

\section{Rise of the biologics $\dagger$}

Antibodies, RNA and gene therapy don't necessarily compete with small molecule drugs - and they all rely on chemistry as well.

DOI: 10.1039/c7md90046e

rsc.li/medchemcomm

For decades, drug research was all about small molecules. Synthetic organic chemistry overlapped almost perfectly that was what you needed to know to make or optimise a new drug candidate. The few exceptions were proteins like insulin - naturally occurring hormones that could be isolated and purified to be given to patients whose own bodies lacked them.

Molecular biology - the ability to manipulate genes and proteins with increasing control - changed this landscape. It began slowly - the first genetically engineered form of insulin was approved in 1982, but this was still the same substance as found in the human body. By the mid-1990s, though, analogues of the insulin protein were being marketed, where the actual amino acid sequence had been changed to alter its properties. In the same era, the first antibodies were approved for human therapy. Here were protein drugs that could, in theory, be 'raised' against all sorts of biological targets, blocking the function of proteins that had proved difficult or impossible to influence with small molecules.

Antibodies now feature prominently on lists of widely used drugs, and their rise is not slowing down at all. Recent antibody failures (such as Eli Lilly's solanezumab, directed at Alzheimer's disease) have been more a case of reaching too far into unknown territory.

$\dagger$ This article was originally published in Chemistry World, first published online on 26 October 2017.
Their rise is worth thinking about in the context of the first RNA-interference therapy - Alnylam's patisiran - which seems to have made it through trials successfully enough to be put in front of the regulators for a final decision. Making drugs out of oligonucleotides has been a lot harder than making them out of proteins - they're far less stable in the blood and generally have to cross into cells to be effective, as opposed to hitting the circulating proteins and cellsurface targets that antibodies excel at. There was a boom in antisense DNA in the early 1990s, which never lived up to the promises of the time. That meant that when RNA emerged as a therapeutic option, people were cautiously skeptical. But even though it's taken a while, and the current drug candidates are still limited to the pharmacologically easiest locations in the body, the technique really does work and should continue to improve. Like antibodies, RNA can be aimed directly at disease targets that small molecule drugs will have a very difficult time touching.

The same goes for the advances in direct gene therapy. The US Food and Drug Administration looks set to approve Spark Therapeutics' Luxturna (voretigene neparvovec) - a viraldelivered gene replacement for a rare form of blindness. Like the first antisense and RNA attempts, it takes advantage of the 'privileged compartment' of the eye: an isolated and much friendlier environment than the bloodstream. A huge amount of work is also going into trying to turn the Crispr gene-editing technology (or some variation thereof) into a human therapy. That will surely be done first by isolating tissues (such as blood stem cells), modifying them, and returning them to a patient's body, but no one wants it to stop there.

Medicinal chemists fall into several schools of thought about these developments. Some haven't given the rise of the biologics as much thought as it deserves, while others have probably given it a bit too much, and perceive a threat to their existence - or at least their employment! But for the most part, these therapies are hitting targets that small molecules have not been able to reach they're expanding the reach of medicine, but not at the expense of medicinal chemistry. Perhaps the real blow has been psychological. Chemists have had to come to terms with the fact that chemistry is no longer the only recourse. It's a tool, a means to an end, and there are more tools appearing all the time. What we have to do, then, is avoid ending up like Norma Desmond in Sunset Boulevard, muttering to ourselves that we're still big, it's the industry that got small. Because it hasn't it's bigger than ever, but there's no way that straight chemistry could maintain its total dominance.

Take heart, though. Those proteins are organic compounds, and the most advanced modifications of them come from organic synthesis. Likewise, the modifications that make oligonucleotides stable enough to use call for very 
difficult chemistry indeed, and it's a good bet that the same will go for Crispr as it advances. Even the small molecules aren't always so small these days, and are thus moving into targets that have never been touched before. Don't curse the tide as it moves in: jump in and surf it!
Derek Lowe (@Dereklowe) is a medicinal chemist working on preclinical drug discovery in the US. He blogs at In the Pipeline. 